\title{
Indicator of the efficiency of value added tax and income tax collection in Ecuador ${ }^{1}$
}

\author{
José Ramírez-Álvarez and Paul Carrillo-Maldonado
}

\begin{abstract}
This paper outlines a methodology to measure the efficiency of revenue collection by tax administrations. The proposed methodology is aimed in particular at developing countries that do not have enough disaggregated information to measure tax gaps (registration, filing, veracity and payment) using traditional methods. The proposed indices are based on estimations of the structural balances of public finances, and rises in the indices can be interpreted as a comprehensive narrowing of tax gaps. The methodology is applied to Ecuador's value added tax (VAT) and income tax, producing results that show that a more efficient tax administration leads to revenue growth.
\end{abstract}

\section{Keywords}

Income tax, value added tax, tax collection, tax evasion, tax administration, evaluation, Ecuador

\section{JEL classification}

$$
\text { H21, H26, H83 }
$$

\section{Authors}

José Ramírez-Álvarez holds a PhD in Economics and is a Professor in the Department of Quantitative Economics at the National Polytechnic School, Ecuador. Email: jose.ramirez@epn.edu.ec.

Paul Carrillo-Maldonado is an Economic Analyst at the Inter-American Development Bank and a PhD candidate in the Doctoral Programme of the Facultad Latinoamericana de Ciencias Sociales (FLACSO). Email: paulcar@iadb.org.

The authors would like to thank Javier Díaz Cassou, Juan Luis Gómez, Alberto Barreix, Edwin Buenaño, Víctor Morales Oñate, Ana Oña, Diana Arias, Ximena Amoroso, Gonzalo Sánchez Lima, Verónica Acurio Vásconez, Liliana Cano and Thais Núñez for their comments. Opinions, errors and omissions are the sole responsibility of the authors and not the institutions. 


\section{Introduction}

Tax management is a crucial administrative function for the State, since it helps to ensure that enough public resources are available for expenditure and investment, and safeguards equity and redistribution in a country's fiscal structure. Tax administrations are responsible for this, which basically comprises tax collection, inspection and payment (Jorratt, 1996).

In essence, tax management covers the management and monitoring of four gaps: registration, filing, veracity and payment. The first of these gaps is the difference between the number of registered taxpayers and the potential population (usually the economically active population in employment). The second gap is the difference between the total number of tax returns that registered, economically active taxpayers should submit and the number of returns actually filed. The payment gap is the difference between the tax paid on time and the amount voluntarily declared by taxpayers. The veracity gap is the difference between the declared amount and that determined by the tax administration following an inspection (Pecho, Sánchez and Peláez, 2012).

A coordinated reduction in these gaps is one of the key goals when formulating strategies for tax administrations and measuring their performance as tax collection entities. The literature on this subject has examined different methods for estimating each gap. Pecho, Sánchez and Peláez (2012) describe these methodologies and present their results for Latin America between 2000 and 2010. However, they also show that the technical feasibility of the methodologies depends on the availability and quality of information from outside the tax administration, potentially preventing comprehensive monitoring of tax management. Alm and Duncan (2014) propose using input-output methodologies (data envelopment analysis) and stochastic frontier analysis to measure the efficiency of the tax administration and its agencies. However, this approach is difficult to apply in emerging economies because of the limited information available on the cost of administrative processes, foreign-source taxpayer transactions and the budget at the administrative-geographical level, among other factors.

This paper proposes a methodology for constructing collection efficiency indices, drawing on macroeconomic information. The methodology is based on estimations of a structural balance of public finances (see Fedelino, Ivanova and Horton, 2009), considering only the tax revenue side; that is to say, eliminating the effects of any economic conditions or tax reforms. The indicator reflects the comprehensive narrowing of the aforementioned tax gaps. This proposal has been applied to the Internal Revenue Service (SRI) of Ecuador and specifically to value added tax (VAT) and income tax in the country. Ecuador is a particularly interesting case because it is a developing country that has achieved substantial increases in revenue in recent years, in clear contrast with previous periods (Almeida and others, 2012).

The results of the exercise show that the efficiency of the SRI has increased since 2006. They also indicate an improvement in VAT collection efficiency from 2007 onward and significant changes between 2006 and 2010 in income tax collection efficiency. Lastly, the results suggest that the behaviour of the SRI can be adapted to possible decreases in revenue caused by factors that are beyond its control.

This paper is divided into sections: the economic theory related to the determinants of tax revenue is presented in section II; the methodology used to construct the efficiency indicators is described in section III; some background on tax collection in Ecuador is provided in section IV; the results obtained for Ecuador are described in section V; and the conclusions are set out in section VI. 


\section{Efficiency and tax collection: theoretical guidelines}

According to Jorratt (1996), there are two main means of increasing tax revenue: establishing new taxes or collecting existing ones with greater efficiency. In a tax context, efficiency is the narrowing or closing of tax gaps through inspections and management strategies that increase taxpayers' risk perception and improve their behaviour. In addition, the Tax Administration Department of Uruguay (2006) and Ricciardi (2007) both state that, in order to measure the efficiency of tax administration, it is necessary to distinguish between three factors that influence tax revenue: economic activity, tax policy and compliance with tax obligations.

Economic activity and tax policy are key elements in the design and structure of any tax system. Economic activity - as a driver of resource generation, usage and transformation - provides an initial estimate of an economic agent's ability to assume a tax burden. Tax policy, meanwhile, establishes how the tax is calculated; that is to say, it determines the taxable event, the taxable person or entity, the tax rate, any exemptions and deductions, and payment of the tax (Martín, 2009).

Great importance is attached to compliance with tax obligations when formulating tax administration strategies and control measures. Control and management actions, whether universal or focused, are designed according to the tax collected, the tax gap, the tax risk and the body of taxpayers that shows signs of undesirable behaviour. ${ }^{2}$

There are several factors that determine tax compliance and hence affect tax collection efficiency. Authors such as Allingham and Sandmo (1972), Andreoni, Erard and Feinstein (1998), Myles (2000), Slemrod and Yitzhaki (2002), Sandmo (2005) and Torgler (2007) analyse several of them from a theoretical point of view. The main factors include risk aversion, the perception of tax controls, the institutional strength of the tax administration, the administrative costs of tax returns, the interaction between taxpayers and tax administrations, the complexity of tax legislation, tax fairness, tax morale and social dynamics.

In practice, these characteristics are difficult to measure because of their social and institutional nature. Regular surveys are often needed to garner public opinion on these issues. However, to do so tax administrations must make use of valuable resources. In addition, field research may be needed, using impact assessments to determine how these characteristics affect tax compliance. ${ }^{3}$

Of the aforementioned factors, risk aversion is key to understanding taxpayer behaviour. Allingham and Sandmo's (1972) model, which has served as the basis for the various theoretical analyses of tax evasion, holds that evasion will increase as the probability of detection, severity of penalties, tax rate and taxpayer risk aversion decrease and income rises (Cowell, 2004). In particular, the last two factors link tax compliance in a different way with taxpayer's characteristics, such as perception and economic activity. There is evidence that risk aversion varies over time and is procyclical (Sancak, Velloso and Xing, 2010). In other words, taxpayers evade less when the economy is booming, since at that point in the business cycle it is less attractive for them to risk engaging in profit-seeking behaviour that would result in a penalty; conversely, taxpayers evade more in recessions, since the scarcity of resources forces them to take the risk and commit fraud. In addition, tax compliance is positively correlated with stronger institutional underpinnings of countries, and negatively correlated with the overall tax burden in the economy (Sancak, Velloso and Xing, 2010).

\footnotetext{
2 Tax risk refers to the probability that the tax administration will incur losses, or that some unfavourable event will occur, as a result of taxpayers' unusual behaviour.

3 The literature on tax evasion has grown rapidly in recent years thanks to impact assessments and particularly field experiments. These assessments generally focus on compliance with income tax and VAT, as well as variables used for filing related returns and for balance sheets (income, sales, deductions and expenses). As part of these assessments, letters, questionnaires or booklets are sent to a group of taxpayers before they fulfil their tax obligations. The information provided usually focuses on deterrence, taxpayer assistance, public services, social standards and morality. Walsh (2012) and Hallsworth (2014) give concise descriptions of several of these assessments. For developing countries, some of the most important experiments may be found in Ortega and Sanguinetti (2013), Pomeranz (2015) and Carrillo, Pomeranz and Singhal (2017).
} 


\section{Methodological strategy}

Constructing the structural balance of public finances to evaluate discretionary fiscal policy measures has been widely discussed in the economic literature. The Organization for Economic Cooperation and Development (OECD) and the International Monetary Fund (IMF) have established similar methodologies for these indicators: both organizations propose econometric estimation of the elasticity of the components of tax revenue and public expenditure with respect to gross domestic product (GDP), in order to purge the effect of the business cycle and use the difference to determine the effect of policy on the overall result of public finances. ${ }^{4}$ The Tax Administration Department of Uruguay uses this methodology to ascertain the efficiency of VAT management in the country, owing to its close relationship with other taxes (Tax Administration Department, 2006).

From a tax perspective, both IMF (see Ebrill and others (2001) or Keen (2013)) and OECD (2008) have proposed assessing VAT-related tax policies using the C-efficiency methodology. C-efficiency is the ratio of VAT revenue to the product of the standard rate and consumption, in nominal pre-tax terms (Keen, 2013). C-efficiency is also used to compare VAT among different countries, as OECD does in its reports (see OECD, 2008).

The VAT and income tax management indices proposed in this document are based on the methodologies of OECD (2008), IMF (Ebrill and others, 2001) and the Tax Administration Department of Uruguay (Tax Administration Department, 2006). The IMF and OECD methodology is used to estimate tax elasticities relative to GDP (or their tax bases) and then the effect of the business cycle is removed. The impact of tax reforms is also estimated, to subtract it from the amount of each tax collected. The remaining component of this process is used to measure the combined efficiency of the tax administration, in accordance with the theoretical guidelines set out above.

There are essentially three stages to estimating the index: (i) seasonal adjustment; (ii) estimation of the long-term elasticities of tax revenue with respect to GDP; and (iii) adjustment of revenue by business cycle. These steps enable estimation of the comprehensive management of the tax administration in the collection of tax revenues. The first step excludes the seasonal effects from the tax variables that are typical of the taxation or economic system, and which may have adverse effects on the econometric estimation. The second step captures the economic activity involved in generating the tax base. The third extracts the cyclical fluctuations in the tax base using the elasticities. This final step adjusts tax revenue by economic cycle and corrects for taxpayer risk aversion in different growth phases. The Tax Administration Department of Uruguay carries out this same process, but its estimate of elasticity suffers from endogeneity between the tax base and the collected amount. In the method proposed in this paper, this problem is corrected by using the dynamic ordinary least squares estimator.

This methodological process enables construction of indicators of the tax administration's collection efficiency, based on identification of the taxes to be studied (VAT or income tax), their macroeconomic tax bases (GDP or consumption) and the reforms that affect the amounts collected. For this proposal, no information is required on commodities, production or imports, among other variables at the industry level, as in the methods reviewed by Pecho, Sánchez and Peláez (2012); nor is it necessary to quantify the processes, their inputs or their level of technology to establish efficiency (see Alm and Duncan, 2014), which is difficult in developing economies.

\footnotetext{
4 In short, the structural balance methodology comprises three steps: estimating the elasticity of the components of total revenues and primary expenditure in relation to GDP (or the tax base); adjusting revenues and expenditures for the business cycle, and; subtracting adjusted primary expenditure and interest payments from adjusted revenues. For further details, see Fedelino, Ivanova and Horton (2009).
} 
To implement this methodology in Ecuador, we used quarterly data covering the period 1993-2014 on VAT collected on domestic transactions, ${ }^{5}$ income tax revenue, GDP and consumption, in current (or nominal) dollars. The tax series are lagged by one period to make the collection date match the tax period in which the tax base was generated. In addition, the X11-ARIMA method is used to seasonally adjust the variables.

\section{Tax elasticities}

The long-term elasticities of VAT and income tax are estimated separately using two econometric models. These models explain the macroeconomic patterns in tax revenue as functions of the tax base (a variable directly associated with economic activity). In the case of VAT, final consumption is used as a proxy for the tax base, while in the case of income tax, GDP is used (see Sevilla, 2004):

$$
\operatorname{Tax}_{t}=\alpha+\beta_{T B}^{T a x} \cdot T B_{t}+\delta \cdot D_{t}+u_{t}
$$

Where $\operatorname{Tax}_{t}$ is the logarithm of VAT or income tax revenue, $T B_{t}$ is the logarithm of the tax base for each tax (consumption or GDP), $\alpha$ is a constant, $\beta_{T B}^{T a x}$ is the elasticity of the tax with respect to its tax base, $D_{t}$ is a vector of dummy variables that control for reforms or structural changes, $\delta$ is the coefficient associated with the dummy variables and $u_{t}$ is the residual.

As previously explained, economic agents may seek to adjust their declared tax base to pay less tax, depending on their level of risk aversion and the penalty they expect if the tax administration detects fraud (Allingham and Sandmo, 1972). This generates endogeneity problems in the estimation of elasticity using ordinary least squares (OLS). Moreover, according to the national accounts manuals, GDP and consumption are already constructed to include the taxes that are generated.

To eliminate this problem, the dynamic ordinary least squares (DOLS) method is used, which modifies the OLS estimate by including lags and advances of the first difference of the independent variables, without affecting the rest of the Gauss-Markov assumptions. Furthermore, this technique is asymptotically equivalent to Johansen's maximum likelihood estimator, with better efficiency and performance on small samples. This method should only be used when there is previous evidence of cointegrating relations among the variables (Stock and Watson, 1993).

Statistical validation of the cointegrating relations was performed in accordance with the methodology of Engle and Granger (1987). In the case of integrated series of order 1, this methodology focuses on verifying that the series in levels contain a unit root, the series in the first difference do not contain a unit root and the linear combination of the series in level does not contain a unit root. The existence of unit roots was evaluated through the Dickey-Fuller and Phillips and Perron tests (see Baum, 2005). Because there could be structural breaks in the economic series due to the 1999 financial crisis in Ecuador and the impact of the 2008 international financial crisis, the Clemente, Montañés and Reyes test (1998) was also used. The results of this process are set out in annex A1.

Structural breaks in the model were identified by means of the cumulative sum of squares test (CUSUMSQ), which allows the periods of greatest instability in the model residuals to be determined (Hansen, 1992; Krämer, Ploberger and Alt, 1988). In addition, the Chow test was used recursively to find the most likely date of the structural break in the variables (Greene, 2007). Based on these tests, it was found that VAT has a structural break in both the mean and slope in the second quarter of 1999. No break was detected in the income tax model (see annex A2).

\footnotetext{
5 VAT on domestic transactions is used because SRI manages this tax revenue. Ecuador's national customs service is responsible for collecting VAT on imports.
} 
Equation (1) also includes dummy variables to isolate the legal changes that affected the structure of the tax system. How to demonstrate the impact of these legal changes (narrative method) has been the subject of extensive discussion in the fiscal policy literature. The most noteworthy proposals include insertion of dummy variables in the prevailing period of the reform, as Edelberg, Eichenbaum and Fisher (1999) did, and the use of ex ante estimates of tax reforms from official records as per Romer and Romer (2010). The latter methodology has been criticized for assuming a certain pattern in reforms, probably conditioned by the information, the duration of the reforms, the time lapse between their announcement and implementation, and economic agents' expectations (Leeper, Walker and Yang, 2008; Perotti, 2007).

Tax reforms have been implemented in Ecuador for economic or institutional reasons and in response to exogenous shocks. Arias and others (2008), Paz and Miño Cepeda (2015) and Carvajal, Carrasco and Álvarez (2012) all provide a history of the country's tax system, presenting the economic and political context of the key tax-related events in Ecuador. For the purpose of this model, dummy variables are included in the period of the legal reforms that modified the tax base and/or the tax rate permanently. In the case of income tax, six reforms were taken into account: (i) between December 1998 and December 1999, income tax was replaced by the financial transactions tax (ICC), with a rate of $1 \%$ on all movements of money or capital pursuant to the Economic Reorganization of Taxation and Finance Act, ${ }^{6}$ with the aim of simplifying procedures and improving tax efficiency; (ii) in January 2000, income tax was reinstated and the financial transactions tax was converted into an advance on the personal income tax at a rate of $0.8 \%$ until November 2000, when it was completely eliminated, ${ }^{7}$ as IMF did not agree with the measure; (iii) in April 2007, the income tax withholding rate was increased from $1 \%$ to $2 \%$ for companies acquiring real estate or entering into a service contract, as part of President Rafael Correa's first round of reforms; (iv) in January 2008, personal income tax was modified through a new tax table, deductions of personal expenses and a new calculation of income tax advances, with the aim of making the tax more progressive; ${ }^{9}$ (v) in December 2009 , advances were established as a minimum and non-refundable tax under the Act to amend the Domestic Tax Regime Act and the Reform Act for Tax Equity in Ecuador, amendments that were made through the adoption of the 2008 Constitution; ${ }^{10}$ and (vi) in December 2010, the Production, Commerce and Investment Code (COPCl) was adopted, a legal framework that established some deductions and exemptions for investment in certain sectors and assets. The Code also established a reduction of 1 percentage point in the corporate income tax rate each year until it reached $22 \%$ in $2013 .{ }^{11}$

In the case of VAT, five reforms were considered, which changed both the tax rate and the tax base. The first reform entered into force in December 1997 and modified the list of VAT-exempt products. ${ }^{12}$ The second reform increased the rate from $10 \%$ to $12 \%$, as part of the measures to counteract the economic crisis the country experienced in the late 1990s. The third was the temporary increase in the VAT rate from $12 \%$ to $14 \% .{ }^{13}$ This measure was withdrawn because it did not have enough political support to maintain it. The fourth reform comprises the changes made by the Reform Act for Tax Equity in Ecuador with respect to VAT, which entered into force in January 2008, exempting public sector purchases from VAT and establishing tax rebates for exporters, among other measures. ${ }^{14}$ The latest reform considered is the elimination of VAT exemptions on purchases by State-owned enterprises. ${ }^{15}$

\footnotetext{
6 Economic Reorganization of Taxation and Finance Act (Law No. 98-17), published in official gazette No. 78 of 1 December 1998.

7 Public Finance Reform Act (Law No. 99-24), published in official gazette No. 181 of 30 April 1999.

8 Official gazette No. 98, 5 June 2007.

9 Reform Act for Tax Equity in Ecuador, published in the third supplement to official gazette No. 242, 29 December 2007.

${ }^{10}$ Act to amend the Domestic Tax Regime Act and the Reform Act for Tax Equity in Ecuador, published in the supplement to official gazette No. 94 of 23 December 2009.

11 Production, Commerce and Investment Code, published in the first supplement to official gazette No. 351, 29 December 2010.

12 Law No. 41, published in official gazette No. 206 of 2 December 1997.

${ }^{13}$ Supplement to official gazette No. 390 of 15 August 2001.

${ }^{14}$ Reform Act for Tax Equity in Ecuador, published in the third supplement to official gazette No. 242, 29 December 2007.

15 State-owned Enterprises Act, published in the first supplement to official gazette No. 48 of 16 October 2009.
} 


\section{Construction of the efficiency indices}

The estimation from equation (1) allows the variation in tax revenues derived from developments in economic activity to be captured. According to the IMF (Ebrill and others, 2001) and OECD (2008) manuals, VAT revenue is adjusted according to the business cycle using the following expression:

$$
\operatorname{Tax}_{t}^{A}=\operatorname{Tax}_{t}\left(\frac{T B_{t}^{T}}{\operatorname{TB}_{t}^{T}}\right)^{\beta_{T B}^{T a x}}
$$

Where $\operatorname{Tax}_{t}^{A}$ is adjusted VAT or income tax revenue per cycle, $T B_{t}^{T}$ is the consumption trend or GDP and $\beta_{T B}^{T a x}$ is the long-term elasticity of the tax with respect to its base. This adjustment allows the procyclical relationship to be extracted from taxpayers' risk aversion, as explained above. If the elasticity is greater than 1, equation (2) establishes that a tax base greater (smaller) than its trend generates an adjusted revenue that is less (greater) than the observed revenue, meaning that:

$$
\begin{aligned}
& T B_{t}>\operatorname{TB}_{t}^{T} \Rightarrow \operatorname{Tax}_{t}^{A}<\operatorname{Tax}_{t} \\
& T B_{t}<T B_{t}^{T} \Rightarrow \operatorname{Tax}_{t}^{A}>\operatorname{Tax}_{t}
\end{aligned}
$$

In other words, tax revenues are undermined in boom periods and compensated in periods of recession. This makes it possible to extract the variations that are characteristic of the economic cycle and correct the underlying bias that introduces less (more) appetite for risk in phases of economic expansion (contraction). Lastly, in order to obtain a measurement of the tax burden resulting from the management of the tax administration, the adjusted revenue is expressed in terms relative to the actual long-term tax base, taking a base year. For the purposes of this paper, 2000 was the reference year.

\section{Tax structure in Ecuador}

Ecuador is a developing Latin American country with a small, open economy. Its production system is primarily export-based, and has been to a greater extent since the first oil boom in the 1970s. According to Díaz (2018), average annual economic growth was 4\% between 1972 and 2015; Díaz also mentions that per capita GDP increased annually by $1.7 \%$ over the same period. These figures are below those for the overall economic development of the region. In addition, the country is dependent on international trade, with the price of oil as a transmission channel.

Different political, economic and natural events drove the country into a crisis in 1999, characterized by persistent inflation (the average between 1990 and 1999 was 39.8\%), mistrust of the monetary system and more than $50 \%$ of the population living in poverty. The authorities made a policy decision to dollarize the Ecuadorian economy. This measure produced results a few years later, with a single-digit inflation rate (for the first time since 2003) and real GDP growth of $4.3 \%$ between 2000 and 2006 . Since 2007 , the country has experienced economic growth of 3.9\%, thanks in particular to the commodity boom that took place throughout Latin America (Díaz, 2018).

One disadvantage of dollarization has been the elimination of traditional monetary and exchange rate policy instruments, leaving fiscal policy solely responsible for maintaining macroeconomic stability. In fact, fiscal policy has evolved the most since 2007, on both the revenue and expenditure sides. The Government of Ecuador increased current and capital expenditure in an effort to accelerate the country's development. The performance of fiscal revenues - especially tax revenues - is presented below in the context of the methodology proposed in the document. ${ }^{16}$

\footnotetext{
${ }^{16}$ For a more detailed review of fiscal policy in Ecuador, see Carrillo (2017), Cueva, Mosquera and Ortiz (2018) and Almeida and others (2012).
} 
Since the 1990s, oil and tax revenues have been the main source of funding (above the line) for public spending. In the 1990s, those two revenues combined represented more than $90 \%$ of the total: on average, their share was $43 \%$ and $50 \%$, respectively. With the creation of the SRI in 1997 , tax revenues strengthened and reached an average share of $59 \%$ by 2006 . Following the reforms and reorganization of tax management that have taken place since 2007, the contribution of taxes has continued to increase, reaching an average of $62 \%$ of total revenues in the period 2007-2015 (see figure 1).

Figure 1

Central government revenue share, 1990-2015

(Percentages)

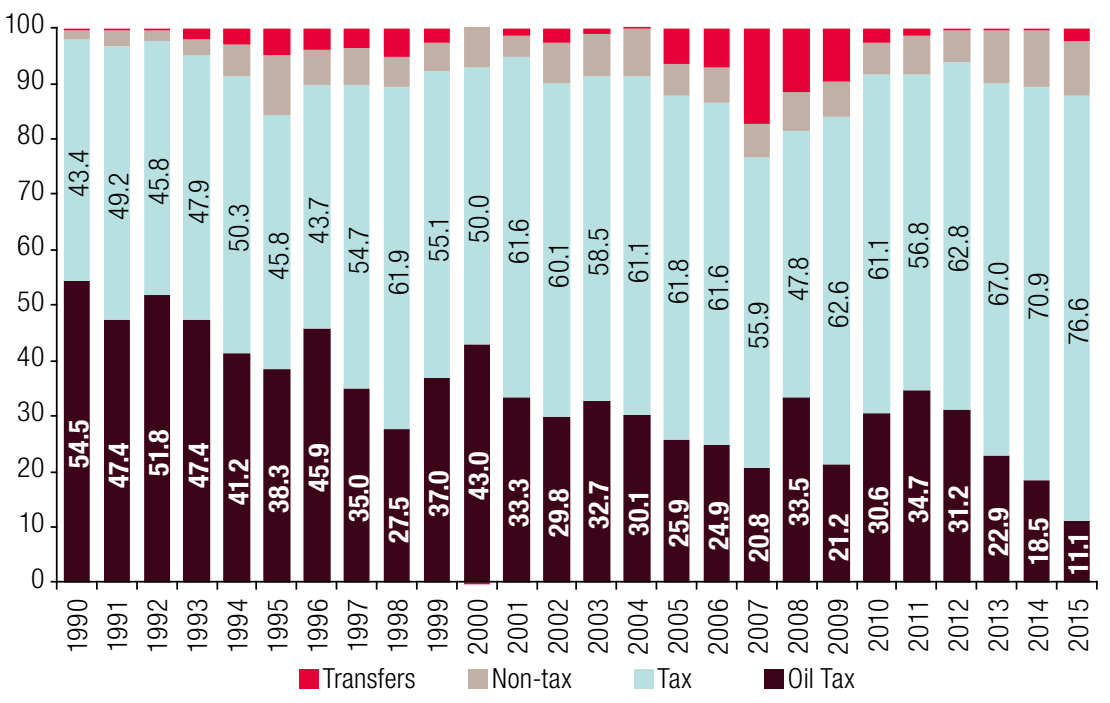

Source: Prepared by the authors, on the basis of data from the Central Bank of Ecuador.

Note: From 2010 onward, the data correspond to the General State Budget (PGE) and are not comparable with previous data, because data from the autonomous entities are included.

Article 300 of the Constitution of the Republic of Ecuador stipulates that the tax system must be governed by the principles of generality, progressiveness, efficiency, administrative simplicity, non-retroactivity, equity, transparency and revenue adequacy (Ecuador, 2008). In addition, the National Plan for Good Living mentions the need to increase State revenue, mainly tax revenues, by increasing the number of taxpayers and controls and penalties for evasion (SENPLADES, 2009). In this regard, the SRI has followed a strategy of downward pressure that includes measures such as facilitating tax return processes for taxpayers who are willing to comply, providing assistance in filing returns, detection as a deterrent for taxpayers who comply if pressured, and using the full force of the law against those who decide not to comply (Carvajal, Carrasco and Álvarez, 2012; Andino, Carrasco and Arteaga, 2012).

The most representative taxes in Ecuador have been VAT and income tax. From 1993 to 2015, these two taxes accounted for more than $80 \%$ of effective revenues, VAT being the most important of the two. Since the 2008 Constitution entered into force, however, income tax has been strengthened with a more progressive tax table, higher withholdings and advances, targeted incentives and benefits, and stricter tax controls, among other measures. As a result, income tax accounted for an average of 32\% of effective revenues between 2009 and 2015 (see figure 2). 
Figure 2

Share of taxes in effective revenues, 1993-2015

(Percentages)

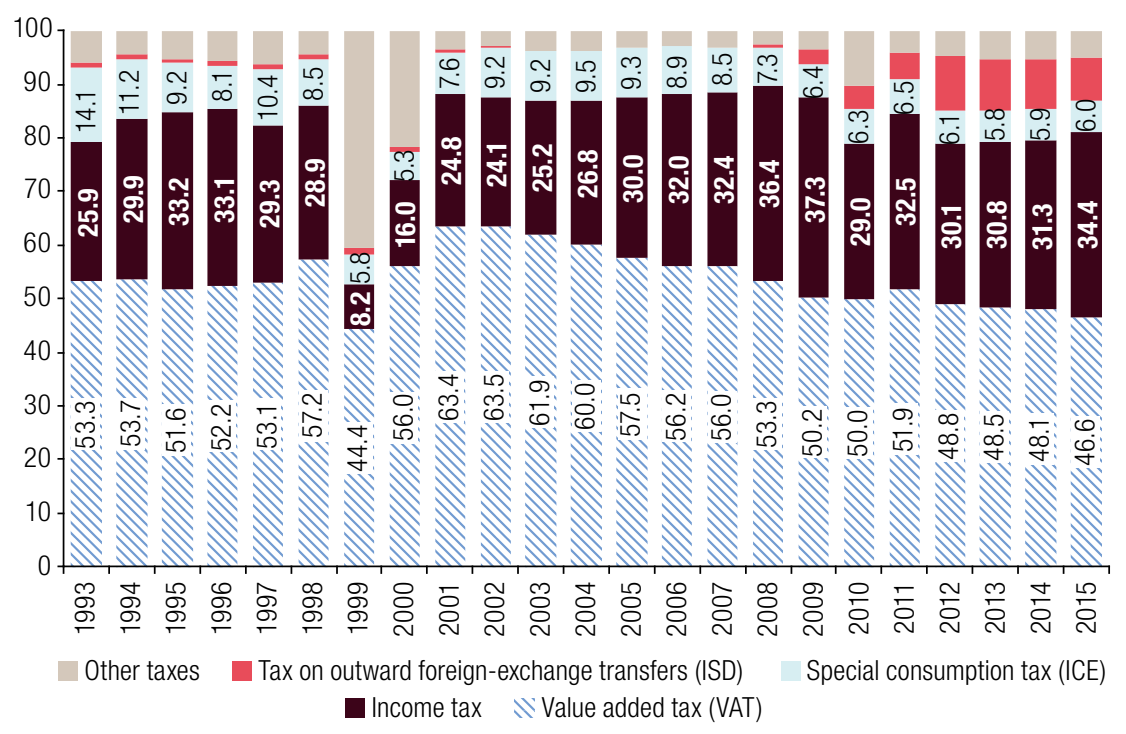

Source: Prepared by the authors, on the basis of data from the Internal Revenue Service of Ecuador.

Note: In 1999 and 2000, income tax was replaced by the financial transactions tax (ICC). The collected amount of tax on outward foreign-exchange transfers for the years prior to 2008 is that levied at airports upon departure from the country.

In recent years, there has been a strong and sustained increase in revenue from these taxes (see figure 3). Some of this growth is likely the result of improved fiscal management by the SRI. However, there are other factors, such as economic activity or recent tax reforms, which may influence tax growth. These factors make it impossible to determine the extent to which increases in revenue are a result of tax administration action, or of reform processes or of the performance of the economy. This is where the proposed efficiency indicators will help measure the effect of tax management.

Figure 3

Tax revenues, 2003-2015

(Millions of nominal dollars)

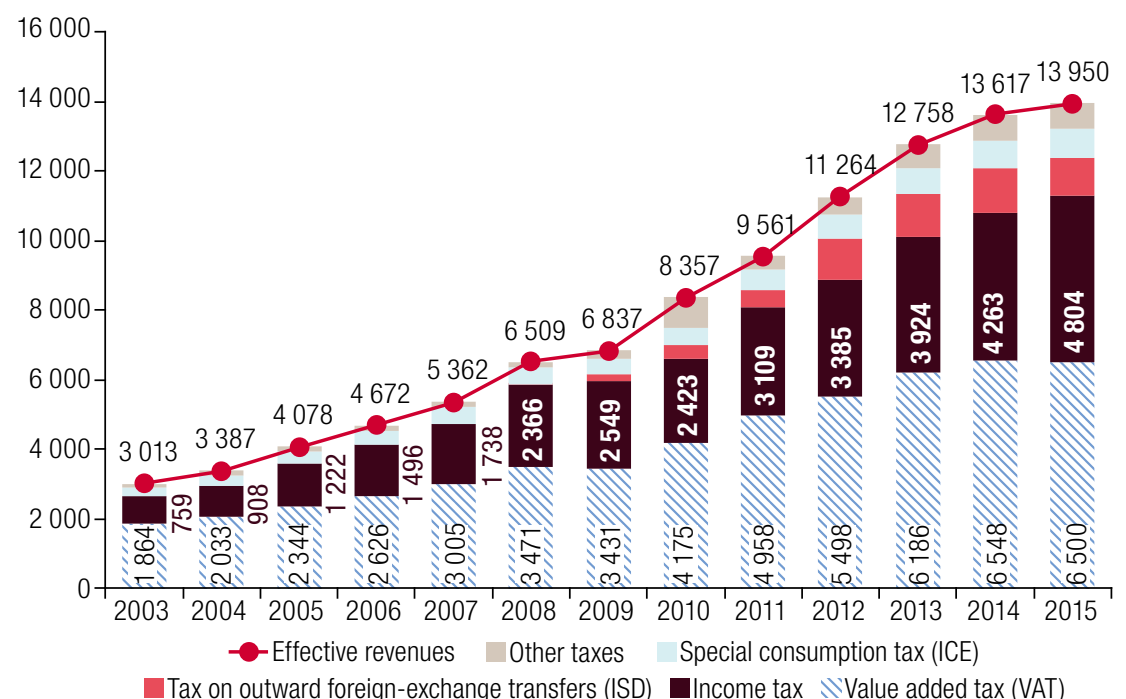

Source: Prepared by the authors, on the basis of data from the Internal Revenue Service of Ecuador. 


\section{Efficiency of the tax administration}

This section outlines the results of applying the described methodology to Ecuador. First, the estimate of the elasticity of the taxes is presented and the result is compared with those obtained in other studies that have estimated the same coefficients in the region. Secondly, the indices are shown on an annual basis for the dollarization period. The quarterly indices are set out in annex A3.

For Ecuador, the elasticity of VAT with respect to consumption is 1.9505, with a significance of $99 \%$. As mentioned above, a structural break was detected in the second quarter of 1999, which shows lower elasticity: 0.4856 (1.9505 - 1.4649). In other words, VAT was less elastic in relation to consumption before the break. Income tax has an elasticity of 2.6669 with respect to GDP, with a significance of $99 \%$ (see table 1).

Table 1

Ecuador: estimation of the long-term elasticities of VAT and income tax using the dynamic ordinary least squares method (DOLS)

\begin{tabular}{|c|c|c|c|c|c|}
\hline Variable & Coefficient & P-value & Variable & Coefficient & P-value \\
\hline Constant & $-18.5125^{\star \star \star}$ & 0.0000 & Constante & $-30.9628^{\star * \star}$ & 0.0000 \\
\hline VAT-Consumption elasticity & $1.9505^{\star \star \star}$ & 0.0000 & Income tax-GDP elasticity & $2.6669^{\star \star \star}$ & 0.0000 \\
\hline Break in the mean & $22.6490^{\star *}$ & 0.0175 & & & \\
\hline Break in the slope & $-1.4649^{\star \star}$ & 0.0160 & & & \\
\hline
\end{tabular}

Source: Prepared by the authors.

Note: $\quad{ }^{* \star *} p<0.01 ;{ }^{* \star} p<0.05,{ }^{*} p<0.1$.

Tax elasticities have been widely calculated in the economic literature. Latin America has been no exception. Table 2 shows the long-term elasticities of VAT and income tax in Latin American countries, as estimated by Ardanaz and others (2015). The results for Ecuador show elasticities of 2.0 and 2.3 for VAT and income tax, respectively, close to the estimates made in this paper, which confirms the country's position above the regional average, with taxes that show greater elasticity.

Through the estimation of elasticity, the tax series were adjusted for the business cycle using equation (2). This same procedure also adjusts taxpayers' risk aversion regarding tax evasion, since, if the cycle is above its trend (boom), agents evade less as more economic resources are generated, while taxpayers evade more in phases of recession because their income is reduced.

The VAT indicator allows three distinct periods to be identified (see figure 4). During the first period, 2000 to 2002, the SRI behaved passively regarding collection of VAT. In the second period, 2003 to 2006, there was a decrease in the indicator below the level for the base year. Andino and Parra (2007) show that VAT evasion rose from 30.1\% to 31.8\% between 2003 and 2005. This could be linked to President Lucio Gutiérrez being removed from office and the ensuing political and institutional crisis in the country.

In the third period, which began in 2007, the SRI made several administrative and operational improvements (annexes and cross-checking of information, training and education (see Carvajal, Carrasco and Álvarez, 2012; Andino, Carrasco and Arteaga, 2012)) which made it possible to increase progressively the efficiency of VAT collection. In 2010, there was only a small drop in efficiency (see figure 4), probably in anticipation of the legal reforms to the Production, Commerce and Investment Code adopted at the end of that year, which established various exemptions and deductions for the production sector. It can be argued that the constant growth that has occurred since 2007 is the result of improvements in complementary information, such as the personal expenses schedule and the tax lottery, among others, which may have affected the tax culture among taxpayers. 
Table 2

Latin America (20 countries): long-term elasticities of VAT and income tax

\begin{tabular}{lcc}
\hline Country & Income tax & Indirect taxes \\
\hline Argentina & 3.0 & 1.1 \\
\hline Barbados & 1.9 & 1.7 \\
\hline Bolivia (Plurinational State of) & 3.0 & 1.5 \\
\hline Brazil & 2.3 & 1.0 \\
\hline Chile & 1.2 & 1.4 \\
\hline Colombia & 1.3 & 1.8 \\
\hline Costa Rica & 2.0 & 0.8 \\
\hline Dominican Republic & 1.8 & 1.4 \\
\hline Ecuador & 2.3 & 2.0 \\
\hline El Salvador & 3.0 & 2.1 \\
\hline Guatemala & 2.2 & 2.0 \\
\hline Guyana & 1.6 & 1.8 \\
\hline Honduras & 1.4 & 3.1 \\
\hline Mexico & 1.3 & 1.8 \\
\hline Panama & 1.3 & 0.7 \\
\hline Paraguay & 0.5 & 2.1 \\
\hline Peru & 2.0 & 1.8 \\
\hline Trinidad and Tobago & 0.6 & 0.7 \\
\hline Uruguay & 2.5 & 3.8 \\
\hline Venezuela (Bolivarian Republic of) & 3.3 & 2.6 \\
\hline Latin America (average) & 1.9 & 1.8 \\
\hline
\end{tabular}

Source: Ardanaz, M. and others, "Structural fiscal balances in Latin America and the Caribbean: new dataset and estimations", IDB Working Paper, No. 579, Washington, D.C., Inter-American Development Bank (IDB), June 2015.

Note: The elasticity of income tax is a simple average of the elasticity of corporate income tax and personal income tax. Indirect taxes are the sum of VAT and excise duties.

Figure 4

Annual average for the VAT efficiency indicator, 2000-2014

(Index, base year $2000=100$ )

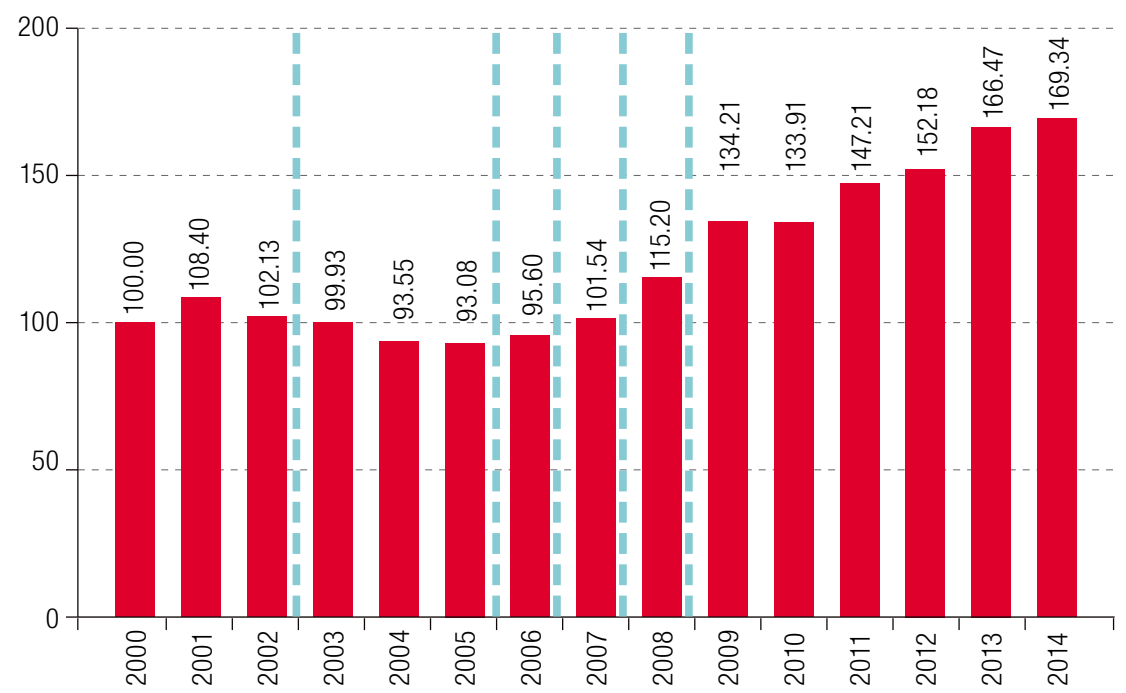

Source: Prepared by the authors.

Note: The dotted lines represent the institutional reforms to the General Operating Regulations of the Internal Revenue Service of Ecuador applied in October 2002, June 2005, June 2006, November 2006, April 2007 and January 2008 (Carvajal, Carrasco and Álvarez, 2012). 
The income tax collection efficiency index is presented in figure 5 . This indicator shows moderate growth in the first five years of dollarization (29.8 points). In 2001, the indicator shows a significant improvement in management by SRI, mainly due to the reintroduction and control of income tax, and the elimination of the financial transactions tax (ICC). When estimating the index, controls were included for the reforms that replaced income tax with the financial transactions tax, but the reintroduction of income tax is likely to have had an indirect effect on tax control that would not be the result of the legal changes.

Figure 5

Annual average for the income tax efficiency indicator, 2000-2014

(Index, base year $2000=100$ )

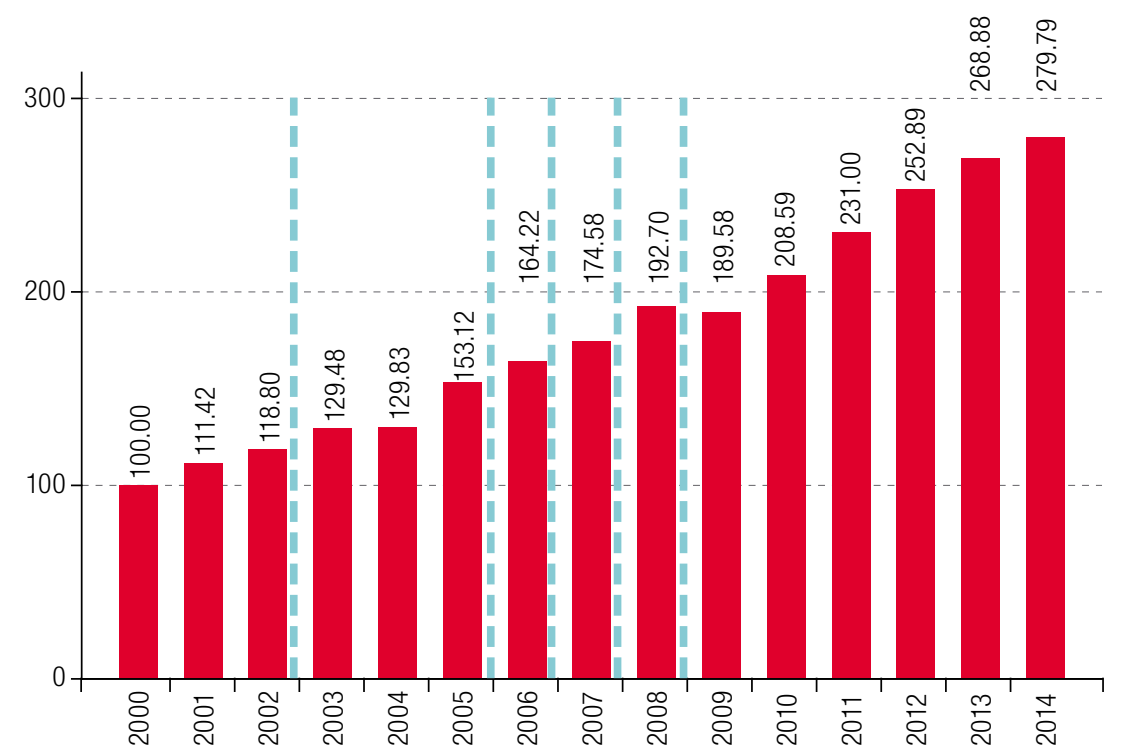

Source: Prepared by the authors.

Note: The dotted lines represent the institutional reforms to the General Operating Regulations of the Internal Revenue Service of Ecuador applied in October 2002, June 2005, June 2006, November 2006, April 2007 and January 2008 (Carvajal, Carrasco and Álvarez, 2012).

The index shows a marked acceleration in growth (59.8 points) between 2004 and 2009, possibly owing to innovation in control and service processes. The tax administration incorporated new technology to strengthen tax control, such as online services and electronic invoicing (Carvajal, Carrasco and Álvarez, 2012; Andino, Carrasco and Arteaga, 2012). In addition, the new management staff of SRI maintained the same policy line on direct taxation, as established by the Constitution of Ecuador (Carrasco, 2012).

In 2009 there is a decrease in income tax collection efficiency, probably because the tax administration anticipated possible tax evasion by taxpayers, as their income would decrease as a result of the global financial crisis. From that point onward, the collection efficiency of the SRI rebounded and the proposed index increases from 208.6 points in 2010 to 279.8 points in 2014.

In short, the collection efficiency indices used in this paper show three different patterns of behaviour from the tax administration. The first is passive behaviour: in the case of VAT, such behaviour was observed between 2000 and 2006, while in the case of income tax it was observed between 2000 and 2004. The second is a pattern of increasing efficiency, which had an effect on revenue following implementation of administrative reforms within the SRI: for VAT this period begins in 2007 and for income tax in 2005. The last pattern of behaviour is of occasional falls in efficiency of the tax administration, which may be rooted in phenomena that are exogenous to the administration itself, such as international shocks or the indirect effects of legal reforms, which reduce the tax base and, by extension, tax revenue. 
In addition, the reforms that sought to strengthen the institutional framework of the SRI (except for that of 2002) clearly succeeded in improving its tax management. The income tax and VAT indices patently show this effect, with increases of 48\% and 43\%, respectively, between 2004 and 2008.

\section{Conclusions}

In taxation, greater efficiency is sought by closing tax gaps through tax administration actions to improve tax collection. Increased tax efficiency is crucial, since it allows sufficient resources to be generated in a timely manner, to sustain public expenditure in the long term.

Although the tax administration has its own information to measure certain gaps, external information is required to continuously evaluate its management and effectiveness. This paper proposes the construction of a collection efficiency indicator from easily accessible macroeconomic information. Based on the structural balance of public finances methodology, this indicator is estimated for Ecuador's VAT and income tax between 1993 and 2014. This indicator is intended as an instrument for monitoring the collection and control activity of the SRI for the comprehensive closing of tax gaps. The main idea behind the construction of the index is the filtering out of the impact of tax reforms, business cycle fluctuations and risk aversion that affect the collection of the main taxes in the country.

The results show that the SRI management has improved the efficiency of VAT and income tax collection over the last decade. In addition, there has been a recovery in the efficiency of VAT collection since 2007, while the efficiency of income tax collection has shown sustained growth over almost all of the period studied, with significant variations between 2005 and 2010. Lastly, the behaviour of the tax administration can be said to be somewhat adaptive to possible decreases in revenue for different reasons (external shocks or legal reforms that extend deductions or exemptions).

\section{Bibliography}

Allingham, M. and A. Sandmo (1972), "Income tax evasion: a theoretical analysis", Journal of Public Economics, vol. 1, No. 3-4, November.

Alm, J. and D. Duncan (2014), "Estimating tax agency efficiency", Public Budgeting \& Finance, vol. 34, No. 3.

Almeida, M. and others (2012), "Ingresos y gasto público en democracia: de la rigidez fiscal al pago de la deuda social", Una nueva política fiscal para el buen vivir: la equidad como soporte del pacto fiscal, Internal Revenue Service, Quito, Ediciones Abya-Yala.

Andino, M. and J. Parra (2007), "Estimación de la brecha de recaudación del IVA e impuesto a la renta de las sociedades por industria", Revista Fiscalidad, No. 1, Quito, Internal Revenue Service.

Andino, M., C. Carrasco and L. Arteaga (2012), "Servicio de Rentas Internas: repensando el nuevo modelo organizacional y de gestión”, Una nueva política fiscal para el buen vivir: la equidad como soporte del pacto fiscal, Internal Revenue Service, Quito, Ediciones Abya-Yala.

Andreoni, J., B. Erard and J. Feinstein (1998), "Tax compliance", Journal of Economic Literature, vol. 36, No. 2, June.

Ardanaz, M. and others (2015), "Structural fiscal balances in Latin America and the Caribbean: new dataset and estimations", IDB Working Paper, No. 579, Washington, D.C., Inter-American Development Bank (IDB), June.

Arias, D. and others (2008), "Historia del sistema tributario ecuatoriano 1950-1999", Revista Fiscalidad, No. 2, Quito, Internal Revenue Service.

Baum, C. (2005), "Stata: the language of choice for time series analysis?", The Stata Journal, vol. 5, No. 1.

Carrasco, C. (2012), "Introducción”, Una nueva política fiscal para el buen vivir: la equidad como soporte del pacto fiscal, Internal Revenue Service, Quito, Ediciones Abya-Yala. 
Carrillo, P. (2017), "El efecto de la política fiscal en expansión y recesión para Ecuador: un modelo MSVAR", Cuadernos de Economía, vol. 36, No. 71, Bogotá, National University of Colombia.

Carrillo, P., D. Pomeranz and M. Singhal (2017), "Dodging the taxman: firm misreporting and limits to tax enforcement", American Economic Journal: Applied Economics, vol. 9, No. 2, April.

Carvajal, D., C. Carrasco and J. Álvarez (2012), "Historia de la tributación en Ecuador: cambios sociales y organizacionales", Una nueva politica fiscal para el buen vivir: la equidad como soporte del pacto fiscal, Internal Revenue Service, Quito, Ediciones Abya-Yala.

Clemente, J., A. Montañés and M. Reyes (1998), "Testing for a unit root in variables with a double change in the mean", Economics Letters, vol. 59, No. 2, May.

Cowell, F. (2004), "Carrots and sticks in enforcement", The Crisis in Tax Administration, H. Aaron and J. Slemrod (eds.), Washington, D.C., Brookings Institution Press.

Cueva, S., R. Mosquera and M. Ortiz (2018), "Ciclicalidad de la política fiscal ecuatoriana desde la dolarización", Reformas y desarrollo en el Ecuador contemporáneo, J. Díaz-Cassou and M. Ruiz Arranz (eds.), Washington, D.C., Inter-American Development Bank (IDB).

Díaz, J. (2018), "La historia económica contemporánea de Ecuador, 1972-2015", Reformas y desarrollo en el Ecuador contemporáneo, J. Díaz-Cassou and M. Ruiz Arranz (eds.), Washington, D.C., Inter-American Development Bank (IDB).

Ebrill, L. and others (eds.) (2001), The Modern VAT, Washington, D.C., International Monetary Fund (IMF).

Ecuador (2008), Constitution of the Republic of Ecuador [online] http://pdba.georgetown.edu/Constitutions/ Ecuador/english08.html.

Edelberg, W., M. Eichenbaum and J. Fisher (1999), "Understanding the effects of a shock to government purchases", Review of Economic Dynamics, vol. 2, No. 1.

Engle, R. and C. Granger (1987), "Co-integration and error correction: representation, estimation, and testing", Econometrica, vol. 55, No. 2, March.

Fedelino, A., A. Ivanova and M. Horton (2009), "Computing cyclically adjusted balances and automatic stabilizers", Technical Notes and Manuals, vol. 9, No. 5, Washington, D.C., International Monetary Fund (IMF), November.

Greene, W. (2007), Econometric Analysis, $6^{\text {th }}$ edition, Boston, Prentice Hall.

Hallsworth, M. (2014), "The use of field experiments to increase tax compliance", Oxford Review of Economic Policy, vol. 30, No. 4.

Hansen, B. (1992), "Testing for parameter instability in linear models", Journal of Policy Modeling, vol. 14, No. 4, August.

Jorratt, M. (1996), "Evaluation of the Collection Capability of the Tax System and of Tax Evasion", paper presented at the Technical Conference of the Inter-American Center of Tax Administrations (CIAT), Viterbo, October.

Keen, M. (2013), "The anatomy of the VAT", National Tax Journal, vol. 66, No. 2, June.

Krämer, W., W. Ploberger and R. Alt (1988), "Testing for structural change in dynamic models", Econometrica, vol. 56, No. 6.

Leeper, E., T. Walker and S. Yang (2008), "Fiscal foresight: analytics and econometrics", NBER Working Paper, No. 14028, Cambridge, National Bureau of Economic Research (NBER), May.

Martín, F. (2009), "La economía de los ingresos tributarios: un manual de estimaciones tributarias", Manual Series, No. 62 (LC/L.3047-P), Santiago, Economic Commission for Latin America and the Caribbean (ECLAC), August.

Myles, G. (2000), "Taxation and economic growth", Fiscal Studies, vol. 21, No. 1, March.

OECD (Organization for Economic Cooperation and Development) (2008), Consumption Tax Trends 2008: VAT/GST and Excise Rates, Trends and Administration Issues, Paris.

Ortega, D. and P. Sanguinetti (2013), "Deterrence and reciprocity effects on tax compliance: experimental evidence from Venezuela", CAF Working Papers, No. 2013/08, Caracas, Development Bank of Latin America (CAF), December.

Paz y Miño Cepeda, J. (2015), Historia de los impuestos en Ecuador: visión sobre el régimen impositivo en la historia económica nacional, Quito, Internal Revenue Service.

Pecho, M., J. Sánchez and F. Peláez (2012), "Estimating Tax Noncompliance in Latin America: 2000-2010", Working Papers, No. 3, Panama, Inter-American Center of Tax Administrations (CIAT), September.

Perotti, R. (2007), "In search of the transmission mechanism of fiscal policy", NBER Working Paper, No. 13143, Cambridge, National Bureau of Economic Research (NBER), June. 
Pomeranz, D. (2015), "No taxation without information: deterrence and self-enforcement in the value added tax", American Economic Review, vol. 105, No. 8, August.

Ricciardi, M. (2007), "Análisis de eficiencia en el IVA y una propuesta para eliminar los impuestos distorsivos", document prepared for second Congreso Metropolitano de Ciencias Económicas, Buenos Aires, November.

Romer, C. and D. Romer (2010), "The macroeconomic effects of tax changes: estimates based on a new measure of fiscal shocks", American Economic Review, vol. 100, No. 3, June.

Sancak, C., R. Velloso and J. Xing (2010), "Tax revenue response to the business cycle", IMF Working Paper, No. WP/10/71, Washington, D.C., International Monetary Fund (IMF), March.

Sandmo, A. (2005), "The theory of tax evasion: a retrospective view", National Tax Journal, vol. 58, No. 4.

SENPLADES (National Secretary of Planning and Development) (2009), Plan Nacional para el Buen Vivir: 2009-2013: construyendo un Estado plurinacional e intercultural, Quito.

Sevilla, J. (2004), Política y técnica tributarias, Manuales de la Escuela de la Hacienda Pública, Madrid, Institute of Fiscal Studies.

Slemrod, J. and S. Yitzhaki (2002), "Tax avoidance, evasion, and administration", Handbook of Public Economics, vol. 3, A. Auerbach, M. Feldstein and E. Saez (eds.), Elsevier.

Stock, J. and M. Watson (1993), "A simple estimator of cointegrating vectors in higher order integrated systems", Econometrica, vol. 61, No. 4, July.

Tax Administration Department (2006), "Eficiencia de la Administración Tributaria en la recaudación: ¿Contribuye la gestión de la DGl a incrementar la recaudación impositiva?", Documento de trabajo, No. 4, July.

Torgler, B. (2007), Tax Compliance and Tax Morale: a Theoretical and Empirical Analysis, Cheltenham, Edward Elgar Publishing.

Walsh, K. (2012), "Understanding taxpayer behaviour - new opportunities for tax administration”, The Economic and Social Review, vol. 43, No. 3. 


\section{Annex A1}

Table A1.1

Clemente-Montañés-Reyes unit root tests for series in levels, series in differences and model disturbances

Series in levels

HO: The series have a unit root

\begin{tabular}{lcrcc}
\hline \multirow{2}{*}{ Variable } & \multirow{2}{*}{ T-statistic } & \multicolumn{3}{c}{ Critical values } \\
\cline { 3 - 5 } & & $1 \%$ & $5 \%$ & $10 \%$ \\
\hline VAT & -3.52 & -5.96 & -5.49 & -5.24 \\
\hline Consumption & -3.17 & -5.96 & -5.49 & -5.24 \\
\hline Income tax & -5.73 & -5.96 & -5.49 & -5.24 \\
\hline GDP & -2.39 & -5.96 & -5.49 & -5.24 \\
\hline
\end{tabular}

Series in differences

$\mathrm{HO}$ : The series have a unit root

\begin{tabular}{lcrrr}
\hline \multirow{2}{*}{ Variable } & \multirow{2}{*}{ T-statistic } & \multicolumn{3}{c}{ Critical values } \\
\cline { 3 - 5 } & & $1 \%$ & $5 \%$ & $10 \%$ \\
\hline VAT & -6.40 & -5.96 & -5.49 & -5.24 \\
\hline Consumption & -8.38 & -5.96 & -5.49 & -5.24 \\
\hline Income tax & -7.56 & -5.96 & -5.49 & -5.24 \\
\hline GDP & -7.56 & -5.96 & -5.49 & -5.24 \\
\hline
\end{tabular}

Disturbances

HO: The series have a unit root

\begin{tabular}{lcrcc}
\hline \multirow{2}{*}{ Variable } & \multirow{2}{*}{ T-statistic } & \multicolumn{3}{c}{ Critical values } \\
\cline { 3 - 5 } & & $1 \%$ & $5 \%$ & $10 \%$ \\
\hline VAT error & -14.56 & -5.96 & -5.49 & -5.24 \\
\hline Income tax error & -10.42 & -5.96 & -5.49 & -5.24 \\
\hline
\end{tabular}

Source: Prepared by the authors.

Note: If the t-statistic is less than a critical value, then the null hypothesis is accepted with the margin of error corresponding to that critical value. 


\section{Annex A2}

Figure A2.1

Cumulative sum of squares test (CUSUMSQ) and Chow test

\section{A. CUSUMSQ test - VAT model}

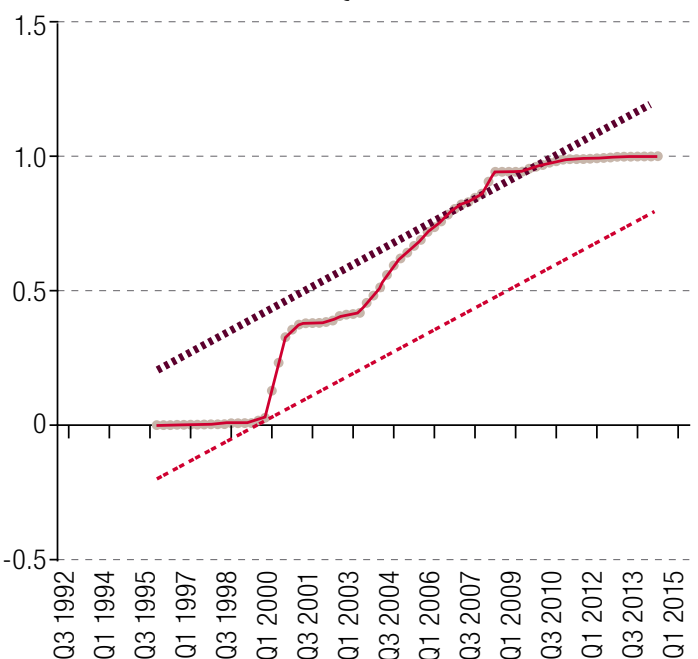

C. CUSUMSQ test - Income tax model

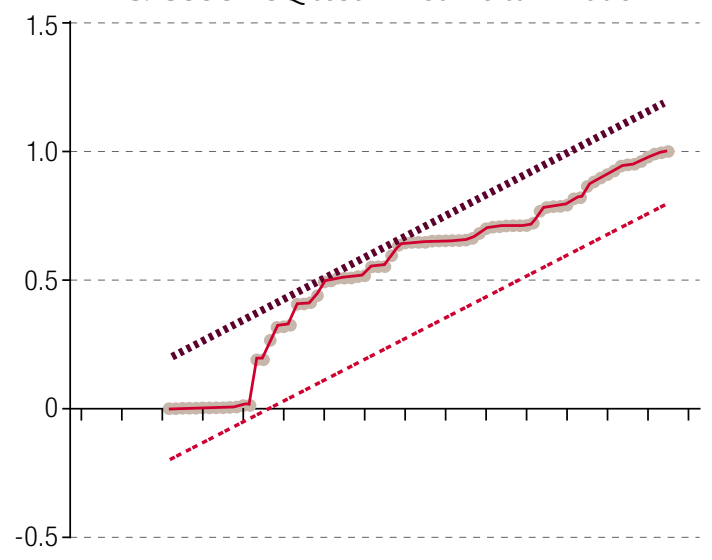

교요

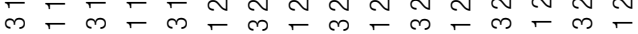

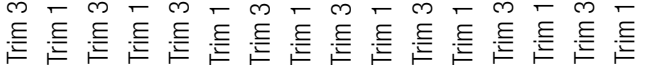

B. Chow test - VAT model

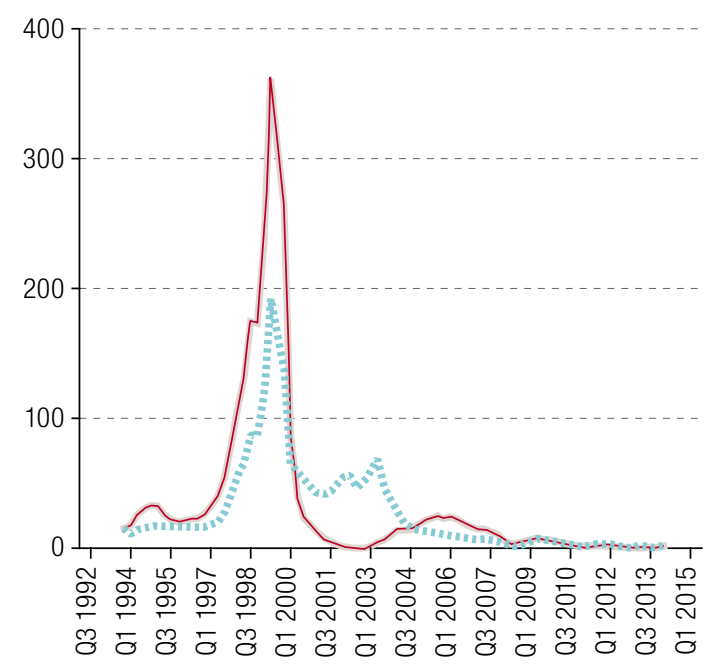

F-statistic break in the slope

— F-statistic break in the mean

n n... F-statistic break in the mean and slope

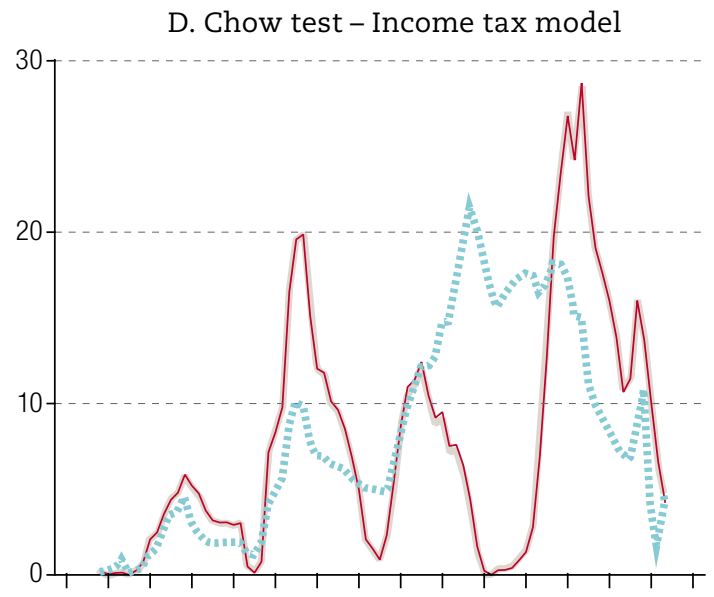

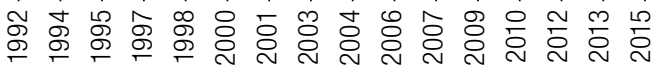
$m=\bar{m}-\bar{m} \sim m \sim m \sim m \sim m-$

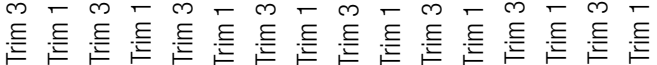

F-statistic break in the slope

— F-statistic break in the mean

. n . . F F-statistic break in the mean and slope

Source: Prepared by the authors. 


\section{Annex A3}

Figure A3.1

Quarterly VAT and income tax efficiency indices and quarterly growth rates (Index, base year $2000=100$ and percentages)

A. VAT efficiency indicator

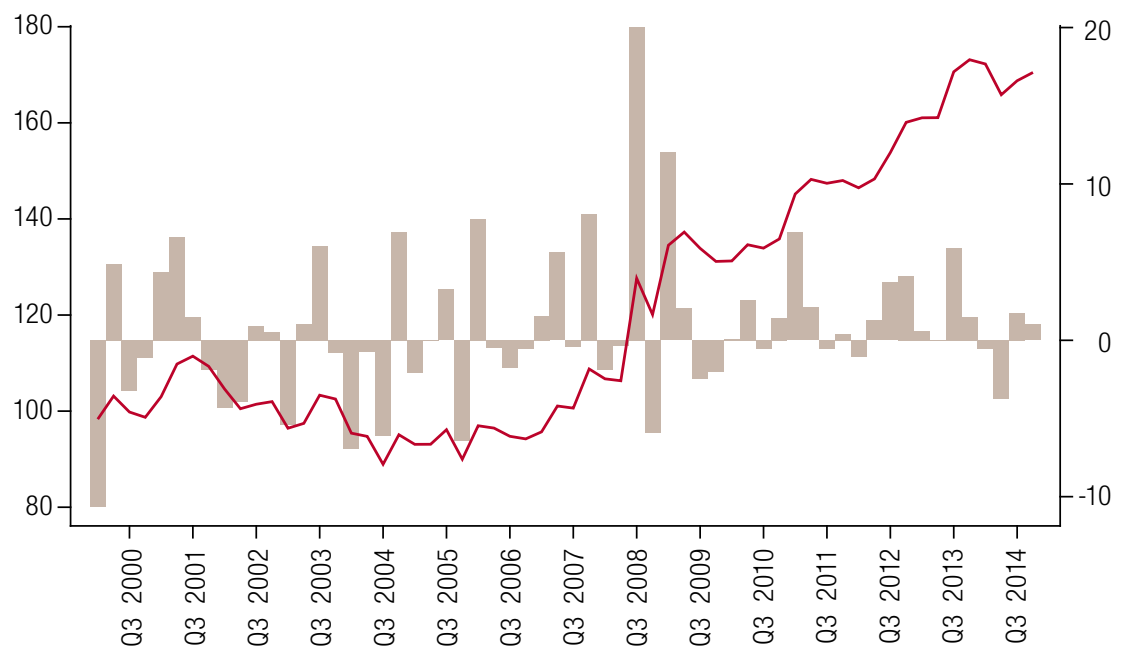

B. Income tax efficiency indicator

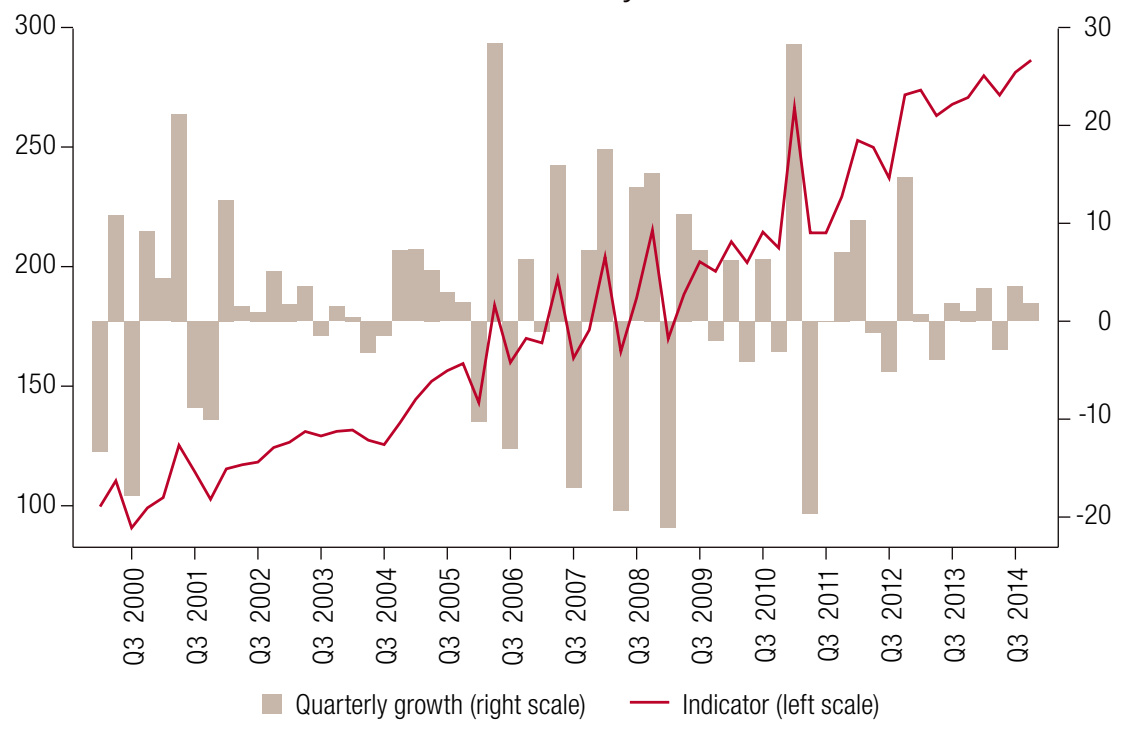

Source: Prepared by the authors. 